\title{
SOME PROBLEMS AND APPROACHES IN CLASSIFICATION OF SITE IN JUVENILE STANDS OF DOUGLAS FIR ${ }^{1}$
}

\author{
BY J. H. G. SMITH and J. W. KER ${ }^{2}$
}

\author{
J. H. G. SMITH
}

J. Harry G. Smith was born at Kamloops in 1925. During the war he served with the R.C.A.F. Coastal Command in lceland as a navigator-bombardier. He was granted his B.S.F. with honors from the University of British Columbia in 1949 and his M.F. cum laude from Yale in 1950. In the field seasons $1949-52$ he undertook research for the B.C. Forest Service into problems of silviculture and management of the Interior spruce-alpine fir type. In 1955 he was granted a Ph.D. by Yale University. His Dissertation was on factors affecting reproduction of Engelmann spruce and alpine fir.

Since receiving his M.F. he has been associated with the Faculty of Forestry as an Instructor in 1950 and as an Assistant Professor from 1952 to the present. He has done research in the University Forest and has served as a consultant to several companies principally Western Plywood and West Tree Farms.

He has served as Secretary Treasurer of the Vancouver Section, C.I.F. and of the Puget Sound Section of the American Society of Photogrammetry. He was Vice-Chairman of the Society of American Foresters Section representing British Columbia and is active in Forest Club and Alumni activities.

At present he is teaching in the fields of Photogrammetry, Fire Control, and Forest Management.

\section{J. W. KER}

John William Ker graduated with honors in 1941 from the University of British Columbia, receiving the degree of Bachelor of Applied Science in Forestry. After six summers and three full years as a Forest Ranger with the B.C. Forest Service, from 1945 to 1948 he undertook mensurational investigations as an Assistant Forester in the Research Division, Victoria, B.C.

In $1948 \mathrm{Mr}$. Ker joined the Department of Forestry, University of British Columbia, as Assistant Professor of Forest Mensuration, under a grant provided by the H. R. MacMillan Export Company. After a one-year leave-of-absence, in 1951 he received the degree of Master of Forestry from Yale University.

Professor Ker is now Associate Professor, Faculty of Forestry, University of British Columbia, teaching mensuration, forest economics and finance. He is a member of the Council of the Association of Professional Foresters of B.C., chairman of the Vancouver Section, Canadian Institute of Forestry, and an executive member of the British Columbia Natural Resources Conference.

${ }^{2}$ Research Paper No. 14. Faculty of Forestry, The University of British Columbia. This project was made possible by a University Research Grant. Assistance of D. Rickson, P. H. Pearse, P. Duffy and K. Maczawa is gratefully acknowledged.

${ }^{2}$ Respectively Assistant Professor and Associate Professor, Faculty of Forestry, The University of British Columbia. 
Although several easily-determined, single-factor approaches to estimation of site quality are available for use in juvenile stands of Douglas fir (Pseudotsuga taxifolia), not one of them is wholly suitable. Conventional height-age relationships in use are based on scanty data for very young stands, are most representative of fully stocked stands, and depend considerably upon the yield table used as a reference.

Recently the growth-intercept method (Wakeley, 1954) has been developed independently for Douglas fir by Wiley (1951) and tested fairly generally by Warrack and Fraser (1955). The growth-intercept method employs the lengths of the first few internodes above breast height as indicators of site quality. This method has the advantages of direct measurement and early classification but indicates current or juvenile site qualities rather than total site capabilities over a long period of time. The utility of another measure of site quality, number of years to reach breast height, is demonstrated by data secured in this study. Schmidt (1954) illustrated possible uses of stump diameters to indicate site quality; unfortunately only past site quality is estimated and direct examination of stumps is necessary. Topographic positions (ridge, upper slope, lower slope, and valley) are, in themselves, often indicative of site quality. Species and abundance of lesser vegetation will also provide indications of the site quality of Douglas fir, but these interrelationships are often complicated and require interpretation by experts. This report illustrates certain problems and possible uses of most of the above-mentioned methods. In addition problems of age-class distribution and succession are discussed. Data used were collected in. Douglas fir types on the University Research Forest at Haney and on Vancouver 1sland.

\section{INTRODUCTION}

As forest management becomes more intensive, the need for early classification of stands increases. In the Douglas fir region little information is available concerning the original site quality of stands that have been logged and burned, or burned. In addition, the possibility of site deterioration is always present and difficult to evaluate. Large areas are unsatisfactorily restocked or, if restocked, often are occupied by trees that are too young for determination of site index by conventional height-age techniques. Since quality of site will influence the amount of harvest permissible under sustained-yield management and will also be indicative of areas on which expenditures of silvicultural funds will be most rewarding, there is a real need for the early evaluation of site quality. Stand improvement, thinning, pruning, and planting should be done first where financial returns are likely to be the greatest.

\section{Conventional Height-Age Relationships}

Certain difficulties encountered in attempting to apply conventional height-age data to very young and to poorly-stocked stands of Douglas fir are illustrated in Figure 1. Differences in opinion concerning the true form of height-age curves are evident in the graphs of Barnes' data (B.C.F.S. 1947) and Spurr's data (1952). Ker's (1952) modification of the height of dominant and codominant trees to the height of dominants only, for purposes of estima- 

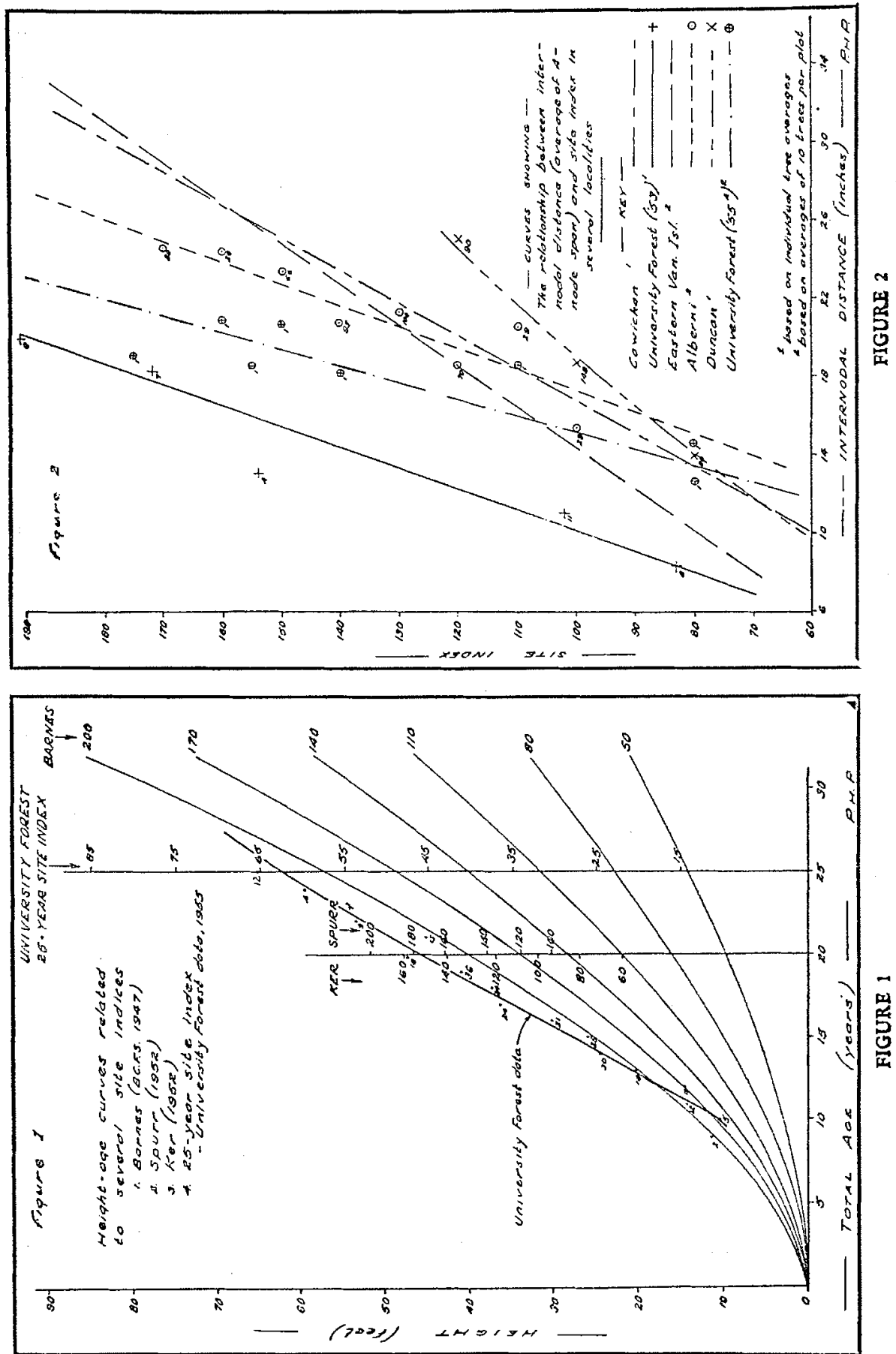
tion of site quality, provides a worthwhile simplification and improvement in accuracy. The influence of a third variable, density of stocking, may be reflected in the curve of height over age plotted from University Forest data in Figure 1.

The area from which these data were collected (Figure 4) was logged and slash-burned prior to 1930 and re-burned accidentally in 1931. A total of 280 trees was measured in 10 representative localities. Only a few seedlings survived the fire of 1931 and re-stocking has been slow and incomplete. The stand density of Douglas fir ranges from 20 to 400 trees per acre, from extremely poor to moderate stocking. Because of this low degree of stocking, trees would be classed as superdominant, dominant, or codominant and would include an abnormally high percentage of dominants. If these trees are to be used for site evaluation by height-age methods, one must decide which yield tables to use, the corrections required to compensate for poor stocking, and the corrections necessary to revise yield-table estimates of years-to-reach-breast-height. As these difficulties appeared insurmountable, a reference age of 25 years was adopted and a sheaf of 25-year site indices was derived from the University Forest data as a basis for comparing other measures of site quality.

\section{The Growth-INTERCEPt Method}

Considerable data have been accumulated to illustrate possible application of the growth-intercept method to the coastal Douglas fir belt of British Columbia. These are summarized in Figure 2. The first relationship was derived by Wiley (1951) who concluded that site index at 100 years equals 6 times internodal distance in inches. Independently, this method was given a preliminary trial at the University Research Forest in 1953. In the summer of 1955 the growth-intercept method was employed near Alberni by MacMillan and Bloedel Limited ${ }^{3}$ and near Duncan by British Columbia Forest Products Limited. ${ }^{3}$ The data which form the basis of the report by Warrack and Fraser (1955) were collected during 1955 on the East Coast of Vancouver Island between Victoria and Campbell River. Additional data on plots ('55A) and on trees ('55B) were collected in 1955 on the University Forest. The University Forest data ('55A) and those of Warrack and Fraser (1955) represent averages of 10 trees; all other data are based on single-tree measurements.

The data of Warrack and Fraser (1955) and of MacMillan and Bloedel (Alberni) are representative of older stands in which reliable estimates of site index are obtainable by standard procedures. Most of the other data are representative of younger stands and contain many of the inconsistencies resulting from application of conventional methods to very young stands. In spite of these shortcomings, there is fair agreement among investigators and the value of the growth-intercept method appears to be substantiated. The considerable differences between University Forest and Duncan data illustrate the need to determine local relationships by the growth-intercept method. The best relationship would appear to be a line halfway between those shown in Figure 2 for Alberni and the East Coast of Vancouver Island.

Because of the novelty of this method, an intensive statistical evaluation of the University Forest data was carried out. Separate regressions of 25-year site index on cumulative height growth in the first, second, third, fourth, and fifth

\footnotetext{
"Thanks are due these companies for permission to use their data.
} 
years after breast height was reached, were calculated for groups of 10 trees. Two groups of 10 trees were taken from each of the topographic locations, ridge, upper slope, and valley. The groups were then combined for each topographic location and for all locations. The significance of these regressions depends on the ratio between the mean sum of squares removed by the regression and the residual variance. These variance ratios (F's) are given in Table 1.

TABLE 1

VARLANCE Ratios as INDICATORS OF THE SIgNIFICANCE OF THE REgRessions of 25-Year Site Index on InTERnodal Distances.

\begin{tabular}{|c|c|c|c|c|c|c|}
\hline & $\begin{array}{r}\text { Years } \\
1\end{array}$ & $\begin{array}{c}\text { grow } \\
2 \\
\text { Vari }\end{array}$ & $\begin{array}{c}\text { above } \\
3 \\
\text { nce ra }\end{array}$ & $\begin{array}{c}\text { breast } \\
4 \\
\text { io }(\mathrm{F})^{1}\end{array}$ & $\begin{array}{c}\text { height } \\
5\end{array}$ & $\begin{array}{c}\text { No. of } \\
\text { trees }\end{array}$ \\
\hline $\begin{array}{l}\text { Ridge } 1 \\
\text { Ridge } 2\end{array}$ & $\begin{array}{r}0.1 \\
22.5\end{array}$ & $\begin{array}{r}0.1 \\
45.4\end{array}$ & $\begin{array}{r}0.1 \\
36.2\end{array}$ & $\begin{array}{r}1.5 \\
43.4\end{array}$ & $\begin{array}{r}3.3 \\
29.1\end{array}$ & $\begin{array}{l}10 \\
10\end{array}$ \\
\hline $\begin{array}{l}\text { Upper slope } 1 \\
\text { Upper slope } 2\end{array}$ & $\begin{array}{l}3.7 \\
8.9\end{array}$ & $\begin{array}{r}8.0 \\
12.2\end{array}$ & $\begin{array}{r}9.5 \\
14.9\end{array}$ & $\begin{array}{l}10.8 \\
19.1\end{array}$ & $\begin{array}{r}7.9 \\
24.2\end{array}$ & $\begin{array}{l}10 \\
10\end{array}$ \\
\hline $\begin{array}{l}\text { Valley } 1 \\
\text { Valley } 2\end{array}$ & $\begin{array}{l}0.2 \\
0.4\end{array}$ & $\begin{array}{l}0.8 \\
2.6\end{array}$ & $\begin{array}{l}2.2 \\
6.6\end{array}$ & $\begin{array}{l}4.2 \\
7.9\end{array}$ & $\begin{array}{l}4.9 \\
5.2\end{array}$ & $\begin{array}{l}10 \\
10\end{array}$ \\
\hline $\begin{array}{l}\text { Ridge } 1 \& 2 \\
\text { Upper slope } 1 \& 2\end{array}$ & $\begin{array}{l}0.6 \\
3.2\end{array}$ & $\begin{array}{l}0.5 \\
8.5\end{array}$ & $\begin{array}{l}1.2 \\
9.1\end{array}$ & $\begin{array}{r}2.5 \\
12.2\end{array}$ & $\begin{array}{r}3.0 \\
12.5\end{array}$ & $\begin{array}{l}20 \\
20\end{array}$ \\
\hline Valley $1 \& 2$ & 0.5 & 4.0 & 6.7 & 10.1 & 7.0 & 20 \\
\hline $\mathrm{R}(1), \mathrm{Us}(1)$, and $\mathrm{V}(1)$ & 5.3 & 13.4 & 13.0 & 20.6 & 23.7 & 30 \\
\hline All R, Us, \& V & 18.8 & 43.4 & 39.9 & 57.9 & 55.8 & 60 \\
\hline
\end{tabular}

${ }^{1}$ Variance ratios that are statistically significant $(p=.05)$ are underlined.

Table 1 illustrates the great variation that is typical of any assessment of site quality. It could be expected that, as sample size and the measured number of height increments are increased, the accuracy of assessment of site index would increase. In general this is true, with occasional exceptions attributable to chance such as in ridge group 2 when highly significant regressions were derived from a few values and in 2- and 4-year internodal distances which are better than expected in the 60-tree sample. Apparently it is not necessary to develop separate relationships for trees growing in various topographic positions. In the above regressions the standard error of estimate of the 25 -year site index of single trees averages about 10 . The relationship between 25 -year site index and internodal growth illustrated in Figure 3 is statistically bighly significant.

Within each locality sampled, all of the Douglas fir trees five years or more in age at breast height were measured. The data recorded for individual 

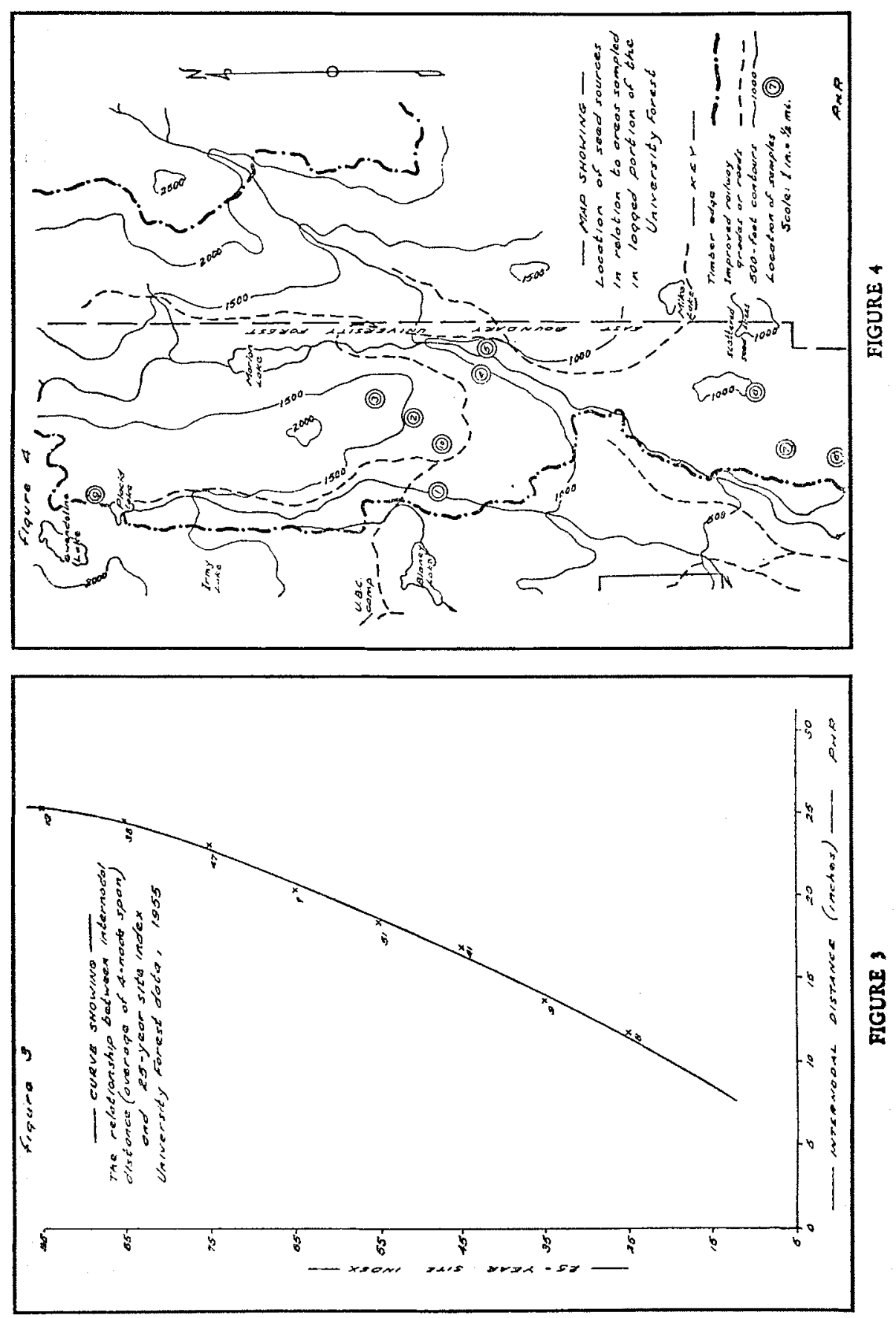
trees and their nearest competing tree are summarized in Table 2. Average d.b.h. increases directly with 25 -year index up to the highest classes of site index. Those trees with 25-year site indices greater than 81 have, for the most part, grown extremely rapidly but are rather younger than average. It is quite possible that rate of height growth and, therefore, indicated site quality of such trees will decrease in the next few decades. At present the trees with the highest 25-year site index have an average d.b.h. closer to the average of all trees than their site index would indicate.

TABLE 2

D.b.h. and Age of Study Trees, and Distance From Nearest Competitive Trees.

\begin{tabular}{|c|c|c|c|c|c|c|c|c|c|}
\hline & 11-20 & 21-30 & $31-40$ & $\begin{array}{c}25-y e \\
41-50\end{array}$ & $\begin{array}{r}\text { ar site } \\
51-60\end{array}$ & $\begin{array}{l}\text { index } \\
61-70\end{array}$ & 71-80 & $81-90$ & $91+$ \\
\hline No. of trees & 2 & 12 & 9 & 41 & 49 & 68 & 48 & 37 & 14 \\
\hline Av. d.b.h., inches & 1.8 & 2.1 & 2.7 & 3.4 & 5.2 & 6.1 & 7.2 & 7.4 & 5.5 \\
\hline \multicolumn{9}{|c|}{ Av. distance to nearest competitor, feet } & 6.9 \\
\hline \multicolumn{10}{|c|}{ Frequency distribution of competitive trees by species } \\
\hline $\begin{array}{l}\text { Douglas fir } \\
\text { Hemlock } \\
\text { Cedar } \\
\text { Others }\end{array}$ & $\begin{array}{l}1 \\
1\end{array}$ & $\begin{array}{l}3 \\
6 \\
3\end{array}$ & $\begin{array}{l}2 \\
3 \\
4\end{array}$ & $\begin{array}{r}12 \\
14 \\
14 \\
1\end{array}$ & $\begin{array}{r}11 \\
21 \\
13 \\
4\end{array}$ & $\begin{array}{r}16 \\
29 \\
19 \\
4\end{array}$ & $\begin{array}{r}12 \\
19 \\
15 \\
2\end{array}$ & $\begin{array}{r}7 \\
19 \\
8 \\
4\end{array}$ & $\begin{array}{r}11 \\
2 \\
1\end{array}$ \\
\hline
\end{tabular}

The distance from each study tree to its nearest competitor was averaged by 25 -year site index and these are surprisingly independent of site class. Only the 81-90 class is associated with a significantly greater spacing between individual trees; in that class, number of trees per acre would be approximately 65 , whereas the average number of trees per acre is about 300 . Both of these figures are higher than the true averages for the area sampled because of the tendency of trees to grow in clumps. Study of the number of trees per acre listed by yield tables for even-aged stands of Douglas fir shows that the spacing between trees on the poor sites should be much less than that on good sites. Since this is not true of the study trees, we may conclude that differences in competition have not been responsible for the observed difference in rates of height growth, and therefore in 25-year site index.

The distribution of number of trees by age and site class was also determined but is not tabulated herein. As might be expected, there was a tendency for the younger trees to be more common in the poorest and best site classes; in the poorest because of competition from older trees, and in the best because of possible faults in prediction owing to the use of anamorphosed curves. That these tendencies were not great was demonstrated by the site indices determined from average height and average age by 5 -year classes. The 10 -year age-class has a corresponding 25-year site index of 60 feet, the 15-year class averages 
66 feet, the 20-year class 60 feet, and the average height of 25-year-old trees was 65 feet.

Because of the range in age classes and their generally good distribution within classes of site index, any bias attributable to cyclic variations in weather should have been removed.

\section{Number of Years to Reach Breast Height}

The period in years required by trees to grow from ground level to breast height may be used as an early criterion of site quality. This measure may be affected considerably by plant competition, by grazing of animals, and by de-budding by birds and animals, yet it is indicative of site quality in many stands. Care must be taken to use only future dominant and codominant trees in appraisal of site quality by this method. Data presented by McArdle, Meyer and Bruce (1949), and used by several other investigators as valid estimates of seedling growth rates, appear to be conservative. The average time required by 454 dominant and codominant Douglas fir near Alberni to reach breast height as saplings was three years less than the time estimated by McArdle, Meyer and Bruce. This element of apparent conservatism is important and should be recognized particularly in discussions of short rotations and in the classification of the site quality of very young stands.

The number of years to reach breast height was estimated for the trees studied on the logged and burned portion of the University Forest. Estimates based on whorl counts were verified by ring counts on a sub-sample of felled saplings. The strong correlation existing between the number of years to reach breast height and the 25-year site index of the study trees is illustrated in Table 3.

TABLE 3

Years to Reach Breast Height Related to Site Quality

\begin{tabular}{lcccccccc}
\hline A. Years to reach breast height: & 3 & 4 & 5 & 6 & 7 & $8+$ \\
\hline $\begin{array}{l}\text { 25-year site index } \\
\text { Number of trees }\end{array}$ & 81.2 & 75.0 & 65.8 & 57.9 & 45.0 & 29.2 \\
& 9 & 68 & 115 & 57 & 20 & 9 \\
\hline B. Site index at 100 years & & 80 & 110 & 140 & 170 \\
\hline & & \multicolumn{3}{c}{ Years to reach breast height } \\
McArdle, Meyer and Bruce (1949) & 10.5 & 9.5 & 8.5 & 7.5 \\
MacMillan and Bloedel (1955) & 8.5 & 5.5 & 4.5 & 4.0 \\
B.C. Forest Service (1948) & 10.5 & & & 6.2 \\
\hline
\end{tabular}

The B.C. Forest Service data tabulated above are taken from curves of average heights of 200 trees on each site. Since dominant and codominant, rather than "average" trees, should be used in site evaluation, the MacMillan and Bloedel data appear to be more satisfactory. The retardation of height growth by suppression and by severe browsing was reported in the 1947 Annual Report of the B.C. Forest Service. Suppression by bracken slowed height 
growth by 57 per cent, and severe browsing by grouse and deer reduced height growth by 71 per cent.

\section{TOPOGRAPHIC POSITIONS}

The individual trees from the University Forest were sorted by four classes of topographic position, i.e. ridge, upper slope, lower slope, and valley. A useful relationship was found to exist between these classes and 25-year site index. Eighty-five trees classed as "valley" averaged 70.7 feet in 25-year site index; 51 "lower slope" trees averaged 68.3 feet; 88 "upper slope" trees averaged 61.6 feet; 55 "ridge" trees averaged 53.9 feet in 25 -year site index. The respective standard errors of the means of these classes were $1.14,2.85,1.33$, and 2.11 . Analysis showed that whereas there was no need to distinguish between "valley" and "lower slope" classes, differences between these and the poorer topographic positions were significant.

\section{LESSER VEgETATION}

The most prominent species of ground vegetation surrounding each of the individual trees measured on the University Forest were recorded. Schmidt (1954) suggested that logged land supporting a ground cover of salal (Gaultherla shallon) is likely to have a site index of less than 120 feet and that abundance of swordfern (Polystichum munitum) is indicative of site indices in excess of 120 feet at 100 years. Several other indicators of good site, mentioned by Schmidt, occurred so infrequently on the study area on the University Forest that they are of no value in this analysis.

When the individual trees were classified by ground vegetation, five quality classes were recognizable. Thirty-nine trees in the "swordfern" class averaged 74.8 feet in 25 -year site index. Forty trees with almost equal amounts of swordfern and salal averaged 70.9 feet in 25-year site index, whereas the largest class, "salal", with 104 trees, averaged 59.8 feet in 25 -year site index. Thirteen trees classed as "salal-Cornus" averaged 58.1 feet and 15 "Cornus" trees averaged 55.6 feet in 25-year site index. Standard errors of these means were: swordfern, 1.62; swordfern-salal, 4.52; salal, 1.57; Cornus, 6.73 feet in 25-year site index. A further 68 trees were characterised by complex combinations of the above species plus bracken (Pteridium equilinum pubescens), and redberried huckleberry (Vaccinium parvifolium), in 21 classes which had little potential for determining site quality. There was an immense range in site quality within classes of vegetational indicators of site, e.g. the 25-year site index of "swordfern" trees ranged from 44 to 95 , that of "salal" trees ranged from 22 to 95. Intensive ecological studies would be required to improve the performance of classes of minor vegetation in differentiating between sites. In any case, the potential value of vegetational indicators of site does not appear to be great for highly variable conditions existing on areas at Haney that have been logged, burned, and re-burned.

\section{Age-Class Distribution and Forest Succession}

The distribution of age classes was examined for 10 groups of trees located within the University Forest as indicated on the map (Figure 4). Five-hundredfoot contours and sources of Douglas fir seed trees are also indicated in Figure 4. 
The age data obtained from counts of annual whorls, summarized in Table 4, indicate that every year some seedlings become established, and that reproduction has occurred irregularly over a long period.

\section{TABLE 4}

Distribution of Age Classes of Douglas Fir Reproduction Following LOGging AND BURNing.

\begin{tabular}{|c|c|c|c|c|c|c|c|c|c|c|c|c|c|c|c|c|c|c|}
\hline $\begin{array}{l}\text { Age (years) } \\
\text { Date of } \\
\text { establishment } \\
\text { Location }\end{array}$ & 9 & 10 & & & & & 194 & & & & & $\begin{array}{l}935 \\
\mathrm{ag}\end{array}$ & & lass) & & 24 & 930 & \\
\hline 1 & - & - & 3 & - & 1 & 4 & 2 & 7 & 3 & 7 & 11 & 3 & 3 & 2 & - & 1 & 2 & 1 \\
\hline 2 & - & - & 1 & 3 & 1 & 4 & 2 & - & 2 & - & 2 & 1 & - & - & 3 & - & - & - \\
\hline 3 & - & 2 & 2 & 1 & - & 1 & $\underline{4}$ & - & 1 & 1 & 1 & - & - & 1 & - & - & - & - \\
\hline 4 & 1 & - & 1 & - & 4 & 1 & 2 & 3 & 1 & 2 & 3 & 2 & - & - & - & - & 1 & - \\
\hline 5 & - & - & - & - & 1 & - & 1 & 2 & - & 2 & $\underline{4}$ & - & - & 1 & - & - & - & - \\
\hline 6 & - & - & - & - & - & - & - & - & 2 & - & 2 & 1 & 1 & 1 & 1 & 2 & 6 & 1 \\
\hline 7 & - & - & - & - & - & 1 & 2 & $\underline{4}$ & 3 & 2 & 1 & $\underline{4}$ & 1 & 1 & - & - & - & - \\
\hline 8 & - & - & 2 & 3 & 5 & 13 & 5 & 1 & 2 & 2 & 1 & 2 & 1 & - & 1 & - & - & - \\
\hline 9 & - & 2 & 1 & 1 & 1 & - & 2 & 3 & 7 & 5 & 5 & 3 & 6 & 2 & - & 1 & 1 & - \\
\hline 10 & 1 & 1 & 2 & 3 & $\frac{6}{-}$ & 6 & 5 & 1 & 4 & 4 & 6 & 3 & 1 & 2 & 2 & - & 2 & - \\
\hline otal & 2 & 5 & 12 & 1 & 19 & 30 & 25 & 21 & 25 & 25 & 36 & 19 & & 10 & 7 & 4 & 12 & 2 \\
\hline
\end{tabular}

Since the ages were appraised by counts of whorls, there is some possibility of error in estimate of ages, but it is not likely to exceed plus or minus one year. It is interesting to note that some trees have survived the fire; almost all of these were established on bare mineral soil adjacent to the railroad grades. Although the poor representation of trees in the 21- to 24-year age groups may be attributed to lack of seed, it is also possible that conditions for germination, survival and establishment were poor after the fire. Improved survival may have been associated with increased shade. For the ages 13-20, age-class distribution is rather similar. The scarcity of sample trees under 12 years in age may be attributed both to the requirement that 5 whorls above breast height be available for measurement and to increased impediment to reproduction provided by shrubs and recent poor seed crops.

The distribution of age classes represented in Table 4 reflects the slow, natural restocking that sometimes follows logging and burning or reburning. It is similar to the older pattern of natural regeneration of Douglas fir on the extensive area of the University Forest that was burned in 1868. Ages of dominant and codominant Douglas fir trees in the stands that developed follow- 
ing the fire of 1868 are highly variable. This variability is illustrated in Table 5 by data collected on 12 plots established by Dr. P. G. Haddock.

TABLE 5

Distribution of age Classes of Douglas Fir in Stand Following A WILd FIRE IN 1868

\begin{tabular}{ccccccc}
\hline Plot No. & \multicolumn{2}{c}{$\begin{array}{c}\text { Age } \\
\text { Average Range }\end{array}$} & Plot No. & \multicolumn{2}{c}{$\begin{array}{c}\text { Age } \\
\text { Average Range }\end{array}$} \\
\hline 1 & 65 & $60-68$ & 7 & 63 & $58-67$ \\
2 & 62 & $59-65$ & 9 & 61 & $55-67$ \\
3 & 75 & $64-80$ & 11 & 62 & $59-67$ \\
4 & 64 & $61-73$ & 12 & 66 & $64-67$ \\
5 & 65 & $60-69$ & 13 & 65 & $60-76$ \\
6 & 64 & $61-73$ & 14 & 64 & $57-68$ \\
\hline
\end{tabular}

The average ages of Douglas fir trees sampled on 25 plots established by students within the same stand were also examined. The average ages of these plots ranged from 52 to 77 , with 8 plots in the age class $52-59$ years, 10 in the class $60-69$, and 7 plots in the age class $70-77$ years.

The data on distribution of age classes illustrate the risks involved in assuming that the stands following logging and burning will be truly even-aged throughout. They also emphasize the advantages to be gained by prompt seeding or planting in order to ensure the establishment of even-aged stands that will utilize the site quickly and fully. The mensurational problems involved in accurate assessment and use of average age for site evaluation and other purposes are of general interest.

Since the data in Tables 4 and 5 represent dominant and codominant trees and exhibit a considerable range in age, it is possible that a number of trees in the lower crown classes originated from seed sown from the oldest "pioneers".

Many of the older trees on the logged and burned portion of the University Forest have produced fair crops of cones which, in spite of scanty sources of pollen, have resulted in a second wave of reproduction. One of these trees was surrounded by more than 20 two-year-old seedlings within a circle fifty feet in diameter. It is to be hoped that the process of natural reproduction of Douglas fir will be accelerated greatly in the near future, but competition from lesser vegetation is becoming an increasingly important problem.

Natural reproduction of western hemlock (Tsuga heterophylla) and western red cedar (Thuja plicata) is also progressing very slowly. In many localities younger and shorter hemlock and cedar are twice as common as Douglas fir. These species seem to have been less well adapted than Douglas fir to the exposed conditions following the second burn. They are, however, more tolerant of shrub competition than Douglas fir, and probably will continue to fill in gaps for some time after reproduction of Douglas fir becomes impossible.

The development of these stands and their gradual improvement in stocking are of great interest and will be studied by means of permanent sample plots. Several degrees of stand improvement, thinning, and pruning are to be applied to selected study areas in the near future. 


\section{Limitations to Single-Factor Approaches}

In each of the methods discussed, wide variation is observed within classes used for ranking site quality from high to low. Many observations and many factors must be considered in order to ensure the best results in site evaluation.

Like all height-age methods, the growth-intercept and years-to-reachbreast-height methods have important faults. Classifications based on juvenile height growth represent current site index rather than long-term site index. They will not indicate the true site quality where conditions for growth are temporarily more or less favorable than usual because of an underlying hardpan, abnormal weather, excesses of nutrients following burning, browsing damage, or temporarily favorable seepage. It must also be assumed that the trees used for site evaluation are truly representative in terms of crown class, vigor, age, spacing, and species. In spite of these limitations, methods based on juvenile height growth provide early and reasonably accurate estimates of site quality that may be determined both easily and rapidly.

Where suitable tree growth is not present, some indication of site quality may be obtained by study of stump diameters, vegetation, or topographic position. The accuracy and ease of application of these methods appears to be inferior to those of juvenile-height-growth measures of site quality.

The best approach would be one based on a synthesis of all measurable effective factors. Determination of the generalized relationship and appropriate weight for each factor would require much further study.

\section{REFERENCES}

British Columbia Forest Service. 1947. Yield Tables for British Columbia. Economics Division, Victoria, B.C. Mimeo.

British Columbia Forest Service, 1948. Annual Report of the Forest Service for 1947. Queen's Printer, Victoria, B.C.

KER, J. W. 1952. An evaluation of several methods of estimating site index of immature stands. For. Chron. 28 (3): 63-74.

McARDLE, R. E., MEYER, W. H. and D. BRUCE. 1949. The yield of Douglas fir in the Pacific Northwest. Revised. U.S. Dept. Agr. Bull. 201, 74 pp.

SCHMIDT, R. L. 1954. A method of estimating site quality of logged land in the coastal Douglas fir belt of British Columbia. B.C. Forest Service, Victoria, B.C. Research Note No. 27, 7 pp. SPURR, S. H. 1952. Forest Inventory. 476 pp. Ronald Press Co., New York.

WAKELEY, P. C. 1954. The growth intercept method of site classification. Recent developments in planting and direct seeding in the southern pine region. Proceedings third annual forestry symposium. School of Forestry, Louisiana State University, Baton Rouge, La.

WARRACK, G. S. and A. R. FRASER. 1955. Estimation of site quality in juvenile Douglas fir stands. B.C. Forest Service, Victoria, B.C. Research Note No. 28, 5 pp.

WLLY, N. A. 1951. Determining site index in young fir stands. Association of British Columbia Foresters, Thesis. 